\title{
Effects of curcumin on growth of human cervical cancer xenograft in nude mice and underlying mechanism
}

\author{
Aixue LIU ${ }^{1,2}$, Ruinian ZHENG ${ }^{3}$, Fan YANG ${ }^{4}$, Li HUANG ${ }^{5}$, Lingyan ZHANG ${ }^{6}$, Jiren ZHANG ${ }^{1 *}$
}

\begin{abstract}
The present study investigated the effects of curcumin (Cur) on growth of human cervical cancer xenograft in nude mice and underlying mechanism. The nude mice modeled with human cervical cancer HeLa cell xenograft were treated with normal saline (control), $3 \mathrm{mg} / \mathrm{kg}$ Cisplatin, 50, 100 and $200 \mathrm{mg} / \mathrm{kg}$ Cur, respectively. The animal body weight and growth of tumor were measured. The expressions of Bax, Bcl-2, p53, p21, HIF-1 $\alpha$, VEGF and MIF protein in tumor tissue were determined. Results showed that, after treatment for 20 days, the tumor mass and tumor volume in 100 and $200 \mathrm{mg} / \mathrm{kg}$ Cur group were significantly lower than control group $(\mathrm{P}<0.05)$. The expressions of Bax, p53 and p21 protein in tumor tissue in $200 \mathrm{mg} / \mathrm{kg}$ Cur group were significantly higher than control group $(\mathrm{P}<0.05)$, and the expressions of $\mathrm{Bcl}-2$, HIF- $1 \alpha$, VEGF and MIF protein in tumor tissue in $200 \mathrm{mg} / \mathrm{kg}$ Cur group were significantly lower than control group $(\mathrm{P}<0.05)$. Cur can inhibit the growth of HeLa cell xenograft in nude mice. The possible mechanism may be related to its up-regulation of Bax, p53 and p21 protein expression in tumor tissue, and down-regulation of Bcl-2, HIF-1a, VEGF and MIF protein expression.
\end{abstract}

Keywords: curcumin; cervical cancer; xenograft; nude mice.

Practical Application: Curcumin may be applied to treatment of human cervical cancer.

\section{Introduction}

Curcumin (Cur) is a polyphenol extracted from the root of turmeric plants. It is used not only in food and condiment in daily life, but also as the anti-inflammatory (Motterlini et al., 2000), anticoagulant (Kim et al., 2012), anti-atherosclerosis (Olszanecki et al., 2005) medicine. In addition, Cur can be applied to the treatment of cancer (Anand et al., 2008), but the mechanism is complex. It is generally believed that, the anti-tumor mechanism of Cur is related to its induction of tumor cell apoptosis and inhibition of tumor cell growth and metastasis (Cheng et al., 2013). In addition, Cur has the function of reversing the drug-resistance of tumors (Li et al., 2011). Cervical cancer is one of the most common malignant tumors in women. The incidence of cervical cancer only seconds to that of the breast cancer (Adams et al., 2009). The chemotherapy is the main method for the treatment of advanced cervical cancer. However, as the currently commonly used chemotherapeutic agents cannot specifically act with the tumor cells, the therapy will result in a lot of side effects, such as myelosuppression, alopecia, nerve damage, gastrointestinal reactions, kidney toxicity, etc., which greatly limit its clinical application (Chung et al., 2007; Kodama et al., 2001; Ke et al., 2012). This study established the nude mice xenograft model of human cervical cancer HeLa cells, and investigated the effects of Cur on the tumor growth and the related mechanism. The objective was to provide the theoretical and experimental basis for the clinical application of Cur.

\section{Materials and methods}

\subsection{Materials}

Human cervical cancer HeLa4 cells were provided by the Institute of Oncology, Guangdong Medical University (Guangzhou, China). Cur (purity 98.5\%) was purchased from Sigma-Aldrich Corp. (MO, USA). Cisplatin (DDP) injection was provided by Jiangsu Hansoh Pharmaceutical Co., Ltd. (Lianyungang, China). $\mathrm{BALB} / \mathrm{c}$ nude mice (SPF grade, female, 4-5 weeks old, 16-20 g) were provided by Guangdong Medical Experimental Animal Center (Foshan, China). The nude mice were single-cage raised in the condition avoiding strong light and noise (temperature $21 \pm 2{ }^{\circ} \mathrm{C}$; relative humidity $30-70 \%$; $12 / 12$-h day-night cycle; free to feed and water). The western blot kits were provided by Shanghai Sangon Biological Engineering Technology And Service Co., Ltd. (Shanghai, China). Other reagents were provided by Sigma-Aldrich Corp. (MO, USA). Electronic balance (FA2004) was provided by Shanghai Shangping Scientific Instrument Co., Ltd. (Shanghai, China). Vernier caliper (8012) was purchased from Shanghai SANTO Hardware Tools Co., Ltd. (Shanghai, China).

\subsection{Establishment of nude mice xenograft model of HeLa cells}

HeLa cells in logarithmic growth phase were taken, and the single-cell suspension $\left(3 \times 10^{10}\right.$ cells $\left./ \mathrm{L}\right)$ was prepared. The right armpit was nude mice was disinfected using iodine, and then 
$0.2 \mathrm{ml}$ HeLa single-cell suspension was subcutaneously inoculated at the right armpit. The growth of xenograft tumor was observed every day, and the diameter was measured. When the diameter of all xenograft tumors was more than $2 \mathrm{~mm}$, the model was considered successfully established.

\subsection{Animal grouping and treatment}

After establishment of HeLa cell xenograft model, 40 nude mice were randomly divided into control, DDP, $50 \mathrm{mg} / \mathrm{kg}$ Cur, $100 \mathrm{mg} / \mathrm{kg}$ Cur and $200 \mathrm{mg} / \mathrm{kg}$ Cur group, 8 nude mice in each group. The nude mice in later 4 groups were intraperitoneally injected with $3 \mathrm{mg} / \mathrm{kg}$ DDP, and 50, 100 and $200 \mathrm{mg} / \mathrm{kg}$ Cur, respectively. The nude mice in control group were intraperitoneally injected with equal volume of normal saline. The administration was performed once per two days, and was last for 20 days. During the administration, the mind state, response, activity and diet were observed.

\subsection{Determination of nude mice body weight and growth of tumor}

At the treatment beginning (day 0) and on the day 5, 10, 15 and 20 after treatment beginning, the body weight of nude mice was measured using electronic balance. On the day 20, all nude mice were executed by cervical dislocation, and the tumor block was stripped, the maximal diameter of the tumor (a) and the short diameter (b) were measured using vernier caliper. Then, the tumor was weighted using electronic balance. The tumor volume was calculated as follows: tumor volume $=\left(a \times b^{2}\right) / 2$. The tumor inhibition rate was calculated as follows: inhibition rate $(\%)=(1$-tumor mass in treatment group/tumor mass in control group) $\times 100 \%$.

\subsection{Determination of expressions of apoptosis-related proteins, hypoxia inducible factor-1 $\alpha$, vascular endothelial growth factor and macrophage migrationinhibitory factor in tumor tissue}

The tumor tissue was homogenized, and the protein was extracted. The expressions of apoptosis-related proteins including B-cell lymphoma-2 (Bcl-2), Bcl-2 associated X protein (Bax), p53 and p21, hypoxia inducible factor-1 $\alpha$ (HIF-1 $\alpha$ ), vascular endothelial growth factor (VEGF) and macrophage migrationinhibitory factor (MIF) in tumor tissue were determined using western blot assays.

\subsection{Statistical analysis}

All statistical analysis was carried out using SPSS13.0 software (SPSS Inc., Chicago, IL, USA). The data were presented as mean $\pm \mathrm{SD}$. The difference between two groups was analyzed using t test. $\mathrm{P}<0.05$ was considered as statistically significant.

\section{Results}

\subsection{Effects of Cur on body weight of nude mice}

During the experimental period, the nude mice in DDP group presented decreased activity, feeding and drinking. The nude mice in other 4 groups presented good general condition, with no occurrence of obvious adverse reaction. Before treatment (day 0 ) and on day 5 after treatment beginning, there was no significant difference of body weight of nude mice among 5 groups $(\mathrm{P}<0.05)$. On the day 10,15 and 20 , the body weight in DDP group was significantly decreased, compared with day 0 and day 5 , respectively $(P<0.01)$. In addition, the body weight in DDP group was significantly lower than each other group at day 10, 15 and 20, respectively $(\mathrm{P}<0.01)$ (Figure 1$)$.

\subsection{Effects of Cur on growth of tumor}

After treatment for 20 days, the tumor mass and tumor volume in DDP, $100 \mathrm{mg} / \mathrm{kg}$ Cur and $200 \mathrm{mg} / \mathrm{kg}$ Cur group were significantly lower than those in control group and $50 \mathrm{mg} / \mathrm{kg}$ Cur group, respectively $(\mathrm{P}<0.05)$. In addition, there was no significant difference of tumor mass or tumor volume among DDP, $100 \mathrm{mg} / \mathrm{kg}$ Cur and $200 \mathrm{mg} / \mathrm{kg}$ Cur group, respectively $(\mathrm{P}>0.05)$. The tumor inhibition rate in DDP, $50 \mathrm{mg} / \mathrm{kg}$ Cur, $100 \mathrm{mg} / \mathrm{kg}$ Cur and $200 \mathrm{mg} / \mathrm{kg}$ Cur group were 42.9\%, 1.7\%, $31.1 \%$ and $39.6 \%$, respectively (Table 1 ).

\subsection{Effects of Cur on expression of apoptosis-related proteins in tumor tissue}

As shown in Figure 2, the relative expression amounts of Bax, p53 and p21 protein in DDP group were significantly higher than that in control group, respectively $(\mathrm{P}<0.05)$, and

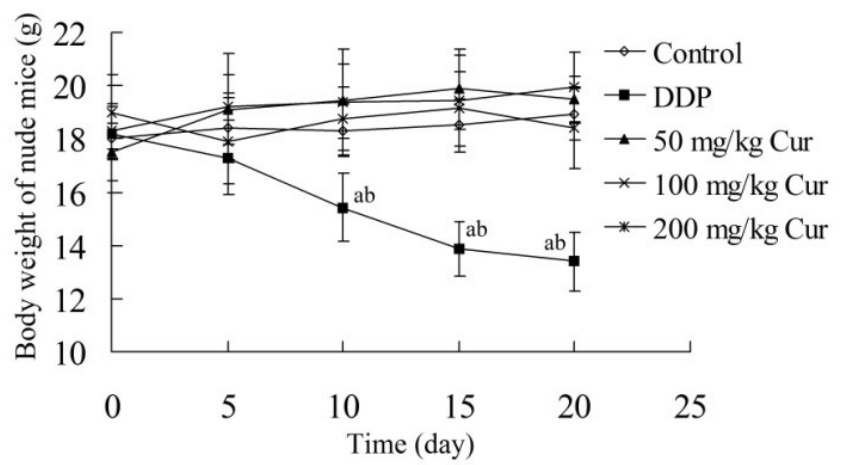

Figure 1. Effects of Cur on body weight of nude mice. ${ }^{a} \mathrm{P}<0.05$ compared with day 0 and day 5 ; ${ }^{\mathrm{b}} \mathrm{P}<0.01$ compared with control group. DDP, cisplatin; Cur, curcumin.

Table 1. Effects of Cur on growth of tumor.

\begin{tabular}{lccr}
\hline \multicolumn{1}{c}{ Group } & Tumor mass $(\mathrm{g})$ & Tumor volume $\left(\mathrm{cm}^{3}\right)$ & Inhibition rate $(\%)$ \\
\hline Control & $1.8 \pm 0.2$ & $1.0 \pm 0.1$ & 0.0 \\
DDP & $1.0 \pm 0.2^{\mathrm{ab}}$ & $0.6 \pm 0.1^{\mathrm{ab}}$ & 42.9 \\
$50 \mathrm{mg} / \mathrm{kg}$ Cur & $1.7 \pm 0.3$ & $1.0 \pm 0.2$ & 1.7 \\
$100 \mathrm{mg} / \mathrm{kg}$ Cur & $1.2 \pm 0.3^{\mathrm{ab}}$ & $0.7 \pm 0.1^{\mathrm{ab}}$ & 31.1 \\
$200 \mathrm{mg} / \mathrm{kg}$ Cur & $1.1 \pm 0.2^{\mathrm{ab}}$ & $0.6 \pm 0.1^{\mathrm{ab}}$ & 39.6 \\
\hline
\end{tabular}

${ }^{\text {ap }}<0.05$ compared with control group; ${ }^{b} \mathrm{P}<0.05$ compared with $50 \mathrm{mg} / \mathrm{kg}$ Cur group. DDP: cisplatin; Cur: curcumin. 
the expression of $\mathrm{Bcl}-2$ protein in DDP group was significantly lower than that in control group $(\mathrm{P}<0.05)$. The expression of Bax protein in $200 \mathrm{mg} / \mathrm{kg}$ Cur group was significantly higher than control group $(\mathrm{P}<0.05)$. The expression of $\mathrm{Bcl}-2$ protein in $100 \mathrm{mg} / \mathrm{kg}$ Cur and $200 \mathrm{mg} / \mathrm{kg}$ Cur group was significantly lower than control group, respectively $(\mathrm{P}<0.05)$. The expression of p53 protein in $200 \mathrm{mg} / \mathrm{kg}$ Cur group and the expressions of p21 protein in $50 \mathrm{mg} / \mathrm{kg}$ Cur group and $100 \mathrm{mg} / \mathrm{kg}$ Cur group were significantly higher than control group, respectively $(\mathrm{P}<0.05)$.

\subsection{Effects of Cur on expression of HIF-1 $\alpha$ and VEGF protein in tumor tissue}

Figure 3 showed that, the relative expression amounts of HIF- $1 \alpha$ and VEGF protein in DDP, $100 \mathrm{mg} / \mathrm{kg}$ Cur and $200 \mathrm{mg} / \mathrm{kg}$ Cur group were significantly decreased, respectively, compared with control group $(\mathrm{P}<0.05)$. In addition, the expression of VEGF protein in $100 \mathrm{mg} / \mathrm{kg}$ Cur group and $200 \mathrm{mg} / \mathrm{kg}$ Cur group were significantly lower than that in $50 \mathrm{mg} / \mathrm{kg}$ Cur group $(\mathrm{P}<0.05)$.

\subsection{Effects of Cur on expression of MIF protein in tumor tissue}

The relative expression amounts of MIF protein in DDP, $50 \mathrm{mg} / \mathrm{kg}$ Cur, $100 \mathrm{mg} / \mathrm{kg}$ Cur and $200 \mathrm{mg} / \mathrm{kg}$ Cur group were significantly decreased, respectively, compared with control group $(\mathrm{P}<0.05)$. There was no significant difference among DDP, 50 mg/kg Cur, 100 mg/kg Cur and 200 mg/kg Cur group $(\mathrm{P}>0.05)$ (Figure 4).
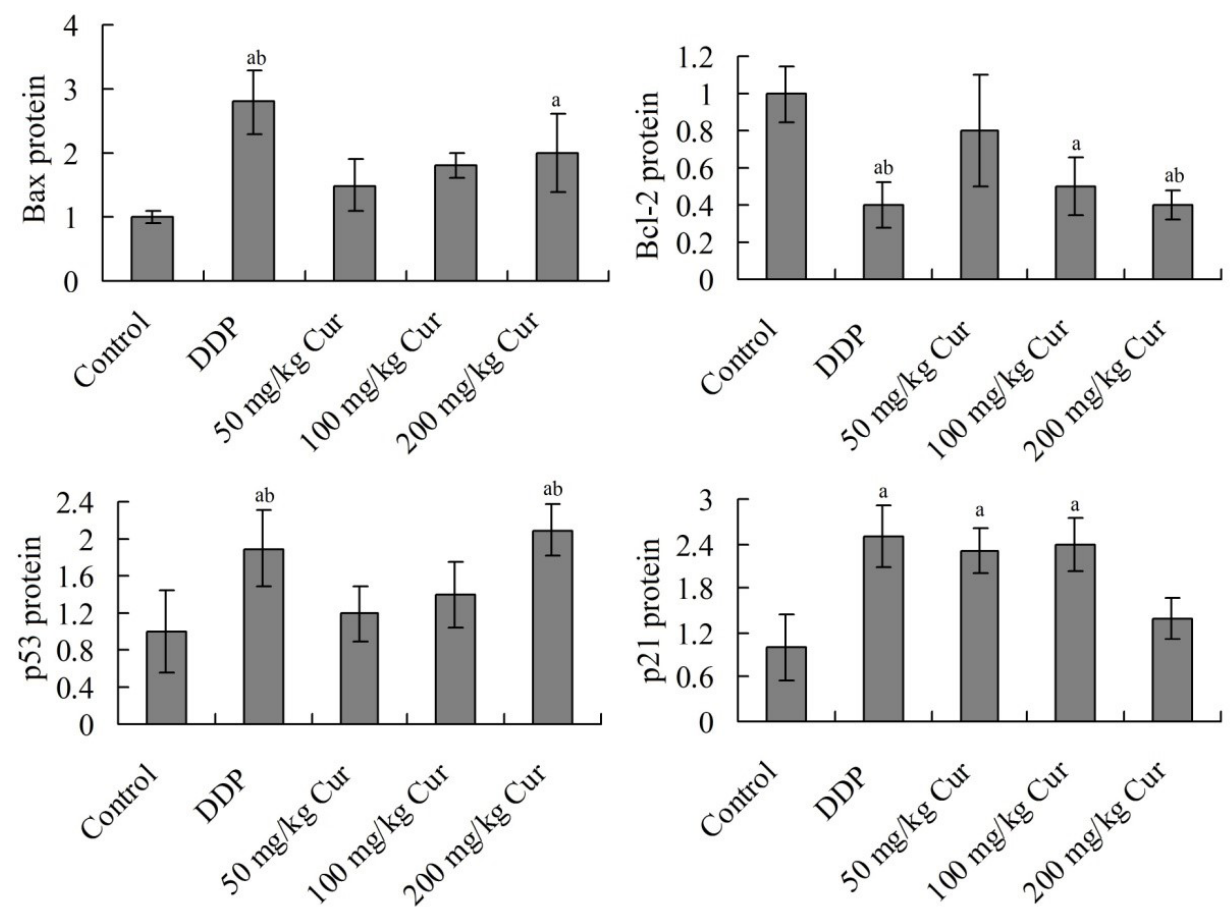

Figure 2. Effects of Cur on expression of apoptosis-related proteins in tumor tissue (times to control group). ${ }^{\text {a }}<0.05$ compared with control group; ' ${ }^{\mathrm{P}}<0.05$ compared with $50 \mathrm{mg} / \mathrm{kg}$ Cur group. DDP, cisplatin; Cur, curcumin; Bax, Bcl-2 associated X protein; Bcl-2, B-cell lymphoma-2.
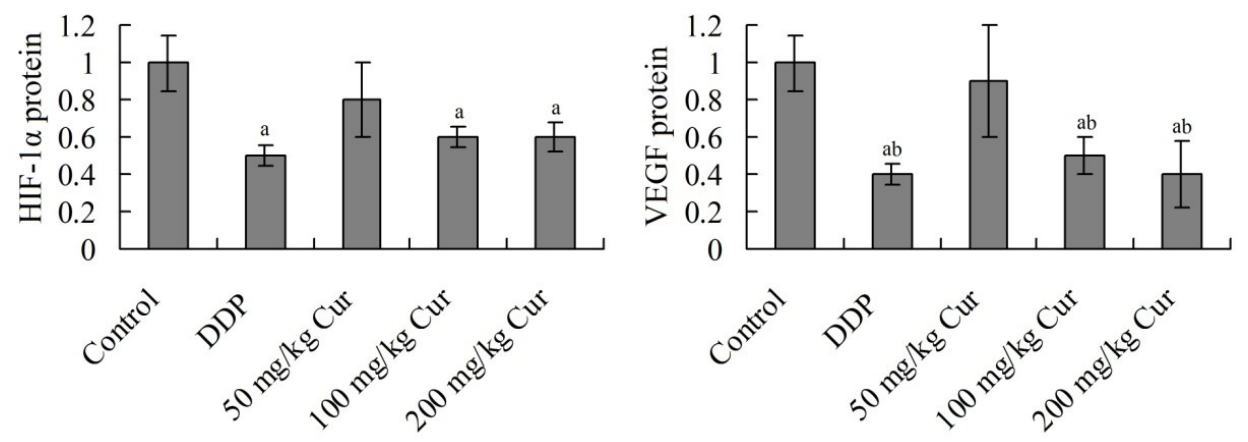

Figure 3. Effects of Cur on expression of HIF-1 $\alpha$ and VEGF protein in tumor tissue (times to control group). ${ }^{\text {a }}<<0.05$ compared with control group; 'P $<0.05$ compared with $50 \mathrm{mg} / \mathrm{kg}$ Cur group. DDP, cisplatin; Cur, curcumin; HIF-1 1 , hypoxia inducible factor-1 1 ; VEGF, vascular endothelial growth factor. 


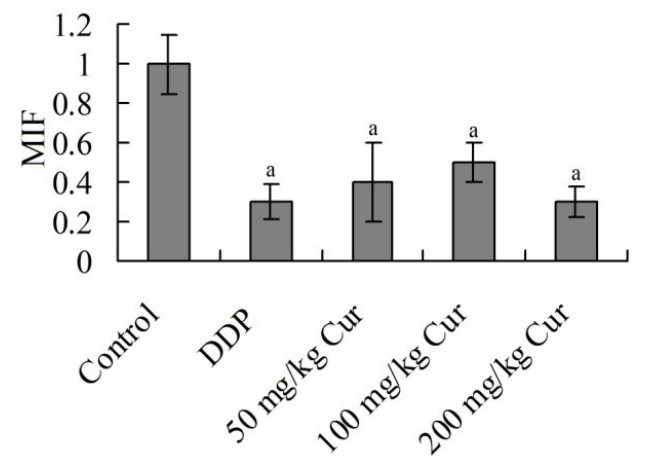

Figure 4. Effects of Cur on expression of MIF protein in tumor tissue (times to control group). ${ }^{\mathrm{P}}<0.05$ compared with control group. DDP, cisplatin; Cur, curcumin; MIF, macrophage migrationinhibitory factor.

\section{Discussion}

Cervical cancer is a common malignant tumor, and the outcome and prognosis of the clinical treatment is not satisfactory. The surgical resection is an effective treatment for early cervical cancer, and the radical hysterectomy is the first choice. In addition, the pelvic lymph node dissection can eliminate the adjacent cancerous tissues (Lee et al., 1989). After surgery, the comprehensive therapies including radiotherapy, chemotherapy and traditional Chinese medicine treatment to prevent the recurrence and metastasis of tumor, and can obtain relative good treatment outcome. However, for patients with advanced cervical cancer, the efficacy of above treatments is not ideal, and the side and toxic effects are more obvious (Abu-Rustum et al., 2001). Therefore, seeking effective anticancer drugs with low-damage and low -toxic side effects is an important topic in the field of medicine.

In recent years, the plant-derived anticancer drugs have presented great potential in drug development. On the one hand, the safe and efficient new anticancer drugs can be screened out from the plants, including paclitaxel (Skwarczynski et al., 2006), camptothecin (Venditto \& Simanek, 2010), etc. On the other hand, the new compounds from plants can provide unique chemical structures for design of more ideal drugs. Cur has advantages of wide source, low price and non-toxic side effect. There are many researches on the anti-tumor effect of Cur (Senft et al., 2010). The possible anti-tumor mechanism of Cur include cytotoxicity, induction of tumor cell apoptosis, inhibition of angiogenesis and blocking of tumor cell growth pathway (Ramsewak et al., 2000; Kunnumakkara et al., 2008). Li et al. (2011) find that, Cur can enhance the efficacy of anticancer drugs, and reduce the drugresistance of tumor cells. Cutler (2008) confirms that, Cur can inhibit the expression of VEGF, and decrease the invasiveness of tumor. Zhang et al. (2010) find that, Cur can inhibit the activity of NF- $\kappa \mathrm{B}$, and decrease the expression of proliferation-related genes, apoptosis-related genes and angiopoientin, thus inhibiting the growth of tumor cells. Results of this study showed that, Cur could significantly inhibit the growth of HeLa cell xenograft in nude mice, and had no obvious adverse effect on the body weight of nude mice.
$\mathrm{Bcl}-2$ gene is the specific survival gene which inhibits the cell apoptosis. It plays an important role in the regulation of cell apoptosis. It can resist various forms of cell death, and prolong the life-span of cells, leading to the increase of cell number (Kim et al., 2006). Bax gene is the apoptosis-promotion gene. Bax gene and $\mathrm{Bcl}-2$ gene belong to the same gene family. Bax can not only inhibit the apoptosis inhibition effect of Bcl-2, but also directly promote the cell apoptosis (Findley et al., 1997). Results of this study showed that, the expression of Bax protein in $200 \mathrm{mg} / \mathrm{kg}$ Cur group was significantly higher than that in control group $(\mathrm{P}<0.05)$, and the expression of $\mathrm{Bcl}-2$ protein in $100 \mathrm{mg} / \mathrm{kg}$ Cur and $200 \mathrm{mg} / \mathrm{kg}$ Cur group was significantly lower than control group, respectively $(\mathrm{P}<0.05)$. This indicates that, Cur can up-regulate the expression of Bax protein and down-regulate the expression of Bcl-2 protein in HeLa cell xenograft in nude mice, which may be related to its inhibitory effects on tumor growth.

p53 is a transcription factor composed of 393 amino acids. It interacts with other intracellular proteins, and is involved in cell cycle control, gene regulation, cell differentiation, apoptosis and tumor suppression (Takahashi, 1997). As a direct downstream product of p53, p21 plays an important role in cell cycle regulation by binding and inhibiting cyclin dependent kinase. In addition, p21 can inhibit the mediated and non-mediated cell apoptosis. In some specific cases, it can promote cell apoptosis (Bao et al., 2006). Results of this study showed that, the expression of $\mathrm{p} 53$ protein in $200 \mathrm{mg} / \mathrm{kg}$ Cur group and the expressions of $\mathrm{p} 21$ protein in $50 \mathrm{mg} / \mathrm{kg}$ Cur group and $100 \mathrm{mg} / \mathrm{kg}$ Cur group were significantly higher than control group, respectively $(\mathrm{P}<0.05)$. This indicates that, the inhibitory effects of Cur on tumor growth may be related to its up-regulation on the expression of p 53 and p21 protein in tumor.

HIF- 1 is composed of $\alpha$ and $\beta$ subunits. HIF- $1 \beta$ is the basic expression protein, and HIF-1 $\alpha$ is an oxygen-regulated protein. It is found that, HIF-1 $\alpha$ is closely related to the occurrence and development of many kinds of tumors, and it is highly expressed in prostate cancer, colon cancer, cervical cancer, lung cancer and so on (Hu et al., 2014). VEGF is an important vascular growth factor. It has stronger regulation effects on vascular endothelial cells proliferation, basement membrane degradation, endothelial cell migration and angiogenesis, with high specificity (Xiao et al., 2004). It is proved that VEGF is a key medium for tumor angiogenesis. The expression of VEGF is high in many animal and human malignant tumors, whether in mRNA level or protein level. Inhibition of VEGF level can inhibit the tumor growth (Ferrara, 2010). As found in this study, the relative expression amounts of HIF- $1 \alpha$ and VEGF protein in DDP, $100 \mathrm{mg} / \mathrm{kg}$ Cur and $200 \mathrm{mg} / \mathrm{kg}$ Cur group were significantly decreased, respectively, compared with control group $(\mathrm{P}<0.05)$. This indicates that, as the same with DDP, Cur can decrease the expressions of HIF- $1 \alpha$ and VEGF protein in tumor tissue.

MIF is a pleiotropic cytokine produced by activated T cells. It does not belong to any currently known cytokine family. It is named due to that it can inhibit the random movement of macrophages in vitro. MIF is a classic proinflammatory cytokine, and can activate the inflammatory reaction through a variety of ways (Cooke et al., 2009). In addition, MIF is a unique cytokine 
which can promote the occurrence of malignant tumors. It presents high expression in a variety of malignant tumors, and accelerates the tumor growth, invasion, and metastasis by promoting the malignant transformation of oncogene, inhibiting the function of tumor suppressor gene p53, and increasing the secretion of extracellular matrix degrading enzymes (Mitchell et al., 2002). In the present study, the relative expression amounts of MIF protein in DDP, $50 \mathrm{mg} / \mathrm{kg}$ Cur, $100 \mathrm{mg} / \mathrm{kg}$ Cur and $200 \mathrm{mg} / \mathrm{kg}$ Cur group were significantly decreased, respectively, compared with control group $(\mathrm{P}<0.05)$. This indicates that, Cur can decrease the expressions of MIF protein in tumor tissue, and there is no dose difference.

\section{Conclusions}

Cur can inhibit the growth of HeLa cell xenograft in nude mice. The possible mechanism may be related to its up-regulation of Bax, p53 and p21 protein expression in tumor tissue, and down-regulation of Bcl-2, HIF-1 $\alpha$, VEGF and MIF protein expression. In addition, Cur has no obvious effect on the body weight of nude mice. This study has provided the theoretical and experimental basis for the clinical application of Cur. However, whether there are other mechanisms of Cur on the tumor inhibition should be further studied.

\section{References}

Abu-Rustum, N. R., Lee, S., Correa, A., \& Massad, L. S. (2001). Compliance with and acute hematologic toxic effects of chemoradiation in indigent women with cervical cancer. Gynecologic Oncology, 81(1), 88-91. PMid:11277656. http://dx.doi.org/10.1006/gyno.2000.6109.

Adams, E. K., Chien, L. N., Florence, C. S., \& Raskind-Hood, C. (2009). The breast and cervical cancer prevention and treatment act in Georgia: effects on time to medicaid enrollment. Cancer, 115(6), 1300-1309. PMid:19189369. http://dx.doi.org/10.1002/cncr.24124.

Anand, P., Sundaram, C., Jhurani, S., Kunnumakkara, A. B., \& Aggarwal, B. B. (2008). Curcumin and cancer: an "old-age" disease with an “age-old" solution. Cancer Letters, 267(1), 133-164. PMid:18462866. http://dx.doi.org/10.1016/j.canlet.2008.03.025.

Bao, G. C., Wang, J. G., \& Jong, A. (2006). Increased p21 expression and complex formation with cyclin E/CDK2 in retinoid-induced pre-B lymphoma cell apoptosis. FEBS Letters, 580(15), 3687-3693. PMid:16765349. http://dx.doi.org/10.1016/j.febslet.2006.05.052.

Cheng, T. S., Chen, W. C., Lin, Y. Y., Tsai, C. H., Liao, C. I., Shyu, H. Y., Ko, C. J., Tzeng, S. F., Huang, C. Y., Yang, P. C., Hsiao, P. W., \& Lee, M. S. (2013). Curcumin-targeting pericellular serine protease matriptase role in suppression of prostate cancer cell invasion, tumor growth, and metastasis. Cancer Prevention Research, 6(5), 495-505. PMid:23466486. http://dx.doi.org/10.1158/1940-6207. CAPR-12-0293-T.

Chung, J. J., Namiki, T., \& Johnson, D. W. (2007). Cervical cancer metastasis to the scalp presenting as alopecia neoplastica. International Journal of Dermatology, 46(2), 188-189. PMid:17269974. http:// dx.doi.org/10.1111/j.1365-4632.2007.03183.x.

Cooke, G., Armstrong, M. E., \& Donnelly, S. C. (2009). Macrophage migration inhibitory factor (MIF), enzymatic activity and the inflammatory response. BioFactors, 35(2), 165-168. PMid:19322762. http://dx.doi.org/10.1002/biof.27.
Cutler, W. B. (2008). Re: Curcumin inhibits MPA-induced secretion of VEGF from T47-D human breast cancer cell. Menopause, 15(6), 1195. PMid:18997590. http://dx.doi.org/10.1097/gme.0b013e3181895c15.

Ferrara, N. (2010). Pathways mediating VEGF-independent tumor angiogenesis. Cytokine \& Growth Factor Reviews, 21(1), 21-26. PMid:20005148. http://dx.doi.org/10.1016/j.cytogfr.2009.11.003.

Findley, H. W., Gu, L., Yeager, A. M., \& Zhou, M. (1997). Expression and regulation of $\mathrm{Bcl}-2, \mathrm{Bcl}-\mathrm{xl}$, and Bax correlate with $\mathrm{p} 53$ status and sensitivity to apoptosis in childhood acute lymphoblastic leukemia. Blood, 89(8), 2986-2993. PMid:9108419.

Hu, X., Fang, Y., Zheng, J., He, Y., Zan, X., Lin, S., Li, X., Li, H., \& You, C. (2014). The association between HIF-1a polymorphism and cancer risk: a systematic review and meta-analysis. Tumour Biology, 35(2), 903-916. PMid:24046090. http://dx.doi.org/10.1007/ s13277-013-1160-X.

Ke, Q. H., Zhou, S. Q., Du, W., Lei, Y., Huang, M., Luo, F., \& Yang, J. Y. (2012). Early efficacy of taxotere and cisplatin chemo-radiotherapy for advanced cervical cancer. Asian Pacific Journal of Cancer Prevention, 13(2), 617-619. PMid:22524834. http://dx.doi.org/10.7314/ APJCP.2012.13.2.617.

Kim, D. C., Ku, S. K., \& Bae, J. S. (2012). Anticoagulant activities of curcumin and its derivative. BMB Reports, 45(4), 221-226. PMid:22531131. http://dx.doi.org/10.5483/BMBRep.2012.45.4.221.

Kim, H., Rafiuddin-Shah, M., Tu, H. C., Jeffers, J. R., Zambetti, G. P., Hsieh, J. J., \& Cheng, E. H. (2006). Hierarchical regulation of mitochondrion-dependent apoptosis by BCL-2 subfamilies. Nature Cell Biology, 8(12), 1348-1358. PMid:17115033. http://dx.doi. org/10.1038/ncb1499.

Kodama, J., Hashimoto, I., Seki, N., Hongo, A., Mizutani, Y., Miyagi, Y., Yoshinouchi, M., \& Kudo, T. (2001). Concurrent chemoradiotherapy for advanced cervical cancer-a pilot study. Gan to Kagaku Ryoho Cancer \& Chemotherapy, 28(3), 351-355. Article in Japanese. PMid:11265403.

Kunnumakkara, A. B., Anand, P., \& Aggarwal, B. B. (2008). Curcumin inhibits proliferation, invasion, angiogenesis and metastasis of different cancers through interaction with multiple cell signaling proteins. Cancer Letters, 269(2), 199-225. PMid:18479807. http:// dx.doi.org/10.1016/j.canlet.2008.03.009.

Lee, Y. N., Wang, K. L., Lin, M. H., Liu, C. H., Wang, K. G., Lan, C. C., Chuang, J. T., Chen, A. C., \& Wu, C. C. (1989). Radical hysterectomy with pelvic lymph node dissection for treatment of cervical cancer: a clinical review of 954 cases. Gynecologic Oncology, 32(2), 135-142. PMid:2910773. http://dx.doi.org/10.1016/S0090-8258(89)80024-1.

Li, Y., Revalde, J. L., Reid, G., \& Paxton, J. W. (2011). Modulatory effects of curcumin on multi-drug resistance-associated protein 5 in pancreatic cancer cells. Cancer Chemotherapy and Pharmacology, 68(3), 603-610. PMid:21116627. http://dx.doi.org/10.1007/s00280010-1515-6.

Mitchell, R. A., Liao, H., Chesney, J., Fingerle-Rowson, G., Baugh, J., David, J., \& Bucala, R. (2002). Macrophage migration inhibitory factor (MIF) sustains macrophage proinflammatory function by inhibiting p53: regulatory role in the innate immune response. Proceedings of the National Academy of Sciences of the United States of America, 99(1), 345-350. PMid:11756671. http://dx.doi.org/10.1073/ pnas.012511599.

Motterlini, R., Foresti, R., Bassi, R., \& Green, C. J. (2000). Curcumin, an antioxidant and anti-inflammatory agent, induces heme oxygenase-1 and protects endothelial cells against oxidative stress. Free Radical Biology \& Medicine, 28(8), 1303-1312. PMid:10889462. http://dx.doi. org/10.1016/S0891-5849(00)00294-X. 
Olszanecki, R., Jawień, J., Gajda, M., Mateuszuk, L., Gebska, A., Korabiowska, M., Chłopicki, S., \& Korbut, R. (2005). Effect of curcumin on atherosclerosis in apoE/LDLR-double knockout mice. Journal of Physiology and Pharmacology, 56(4), 627-635. PMid:16391419.

Ramsewak, R. S., DeWitt, D. L., \& Nair, M. G. (2000). Cytotoxicity, antioxidant and anti-inflammatory activities of curcumins I-III from Curcuma longa. Phytomedicine, 7(4), 303-308. PMid:10969724. http://dx.doi.org/10.1016/S0944-7113(00)80048-3.

Senft, C., Polacin, M., Priester, M., Seifert, V., Kögel, D., \& Weissenberger, J. (2010). The nontoxic natural compound Curcumin exerts antiproliferative, anti-migratory, and anti-invasive properties against malignant gliomas. BMC Cancer, 10(1), 491. PMid:20840775. http:// dx.doi.org/10.1186/1471-2407-10-491.

Skwarczynski, M., Hayashi, Y., \& Kiso, Y. (2006). Paclitaxel prodrugs: toward smarter delivery of anticancer agents. Journal of Medicinal Chemistry, 49(25), 7253-7269. PMid:17149855. http://dx.doi. org/10.1021/jm0602155.
Takahashi, R. (1997). Role of p53 tumor suppressor gene and Fas/ Apo-1 in induction of apoptosis and differentiation of cancer cells. Leukemia, 11(Suppl 3), 331-333. PMid:9209381.

Venditto, V. J., \& Simanek, E. E. (2010). Cancer therapies utilizing the camptothecins: a review of the in vivo literature. Molecular Pharmaceutics, 7(2), 307-349. PMid:20108971. http://dx.doi. org/10.1021/mp900243b.

Xiao, X., Liu, J., \& Sheng, M. (2004). Synergistic effect of estrogen and VEGF on the proliferation of hemangioma vascular endothelial cells. Journal of Pediatric Surgery, 39(7), 1107-1110. PMid:15213909. http://dx.doi.org/10.1016/j.jpedsurg.2004.03.067.

Zhang, C., Li, B., Zhang, X., Hazarika, P., Aggarwal, B. B., \& Duvic, M. (2010). Curcumin selectively induces apoptosis in cutaneous T-cell lymphoma cell lines and patients' PBMCs: potential role for STAT-3 and NF-kappaB signaling. The Journal of Investigative Dermatology, 130(8), 2110-2119. PMid:20393484. http://dx.doi. org/10.1038/jid.2010.86. 